Indexed by:

Asinta

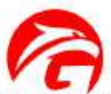

GARUDA

Crossref

crossmark

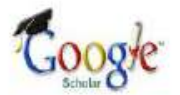

Dimensions

Sonesearch

Manuscripts screening

tools:

turniting)

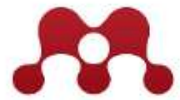

MENDELEY

G grammarly

\title{
KAJIAN KONSEP IMAGEABILITY DAN PERMEABILITY DALAM PENGEMBANGAN KAWASAN PUSAT KOTA BARU PARAHYANGAN
}

\section{Putra Fajar}

Universitas Muhammadiyah

Jakarta, Jakarta, Indonesia

Jalan Cempaka Putih Tengan No. 27,

RT.11/RW.5, Cemp. Putih Tim., Kec.

Cemp. Putih, Kota Jakarta Pusat,

Daerah Khusus Ibukota Jakarta

10510

\author{
Ari Widyati Purwantiasning \\ Universitas Muhammadiyah \\ Jakarta, Jakarta, Indonesia \\ Jalan Cempaka Putih Tengan No. 27, \\ RT.11/RW.5, Cemp. Putih Tim., Kec. \\ Cemp. Putih, Kota Jakarta Pusat, \\ Daerah Khusus Ibukota Jakarta 10510
}

Key words:

Imageability, Permeability, Area, City center

Doi:

10.17509/jaz.v4i1.28307

Cite article:

Fajar, P., dan Purwantiasning, A. W. (2021). Kajian Konsep Imageability Dan Permeability Dalam Pengembangan Kawasan Pusat Kota Baru Parahyangan. Jurnal Arsitektur Zonasi, 4(1), 21-33. https://doi.org/doi.org/10.17509/jaz.v4i1.28307

Akses online:

untuk naskah lengkap tersedia di: https://ejournal.upi.edu/index.php/jaz/issue/archive 
http://ejournal.upi.edu/index.php/jaz - e-mail: jurnal.zonasi@gmail.com dan jurnal_zonasi@upi.edu doi.org/10.17509/jaz.v4i1.28307

\section{KAJIAN KONSEP IMAGEABILITY DAN PERMEABILITY DALAM PENGEMBANGAN KAWASAN PUSAT KOTA BARU PARAHYANGAN}

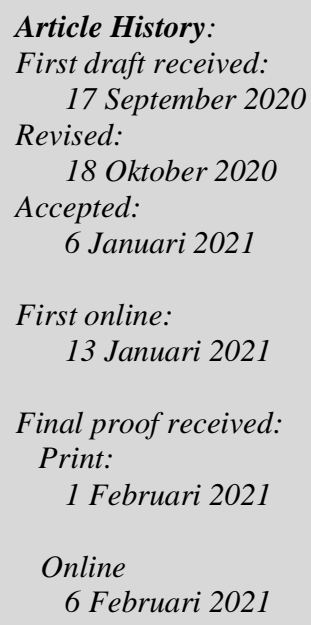

Jurnal Arsitektur ZONASI is indexed and listed in several databases:

SINTA 4 (Arjuna)

GARUDA (Garda Rujukan Digital)

Google Scholar

Dimensions

oneSearch

BASE

Member:

Crossref

RJI

APTARI

FJA (Forum Jurna Arsitektur)

IAI

AJPKM

\author{
Putra Fajar ${ }^{1}$ \\ Ari Widyati Purwantiasning ${ }^{2}$ \\ 1,2 Universutas Muhammadiyah Jakarta, Jakarta, Indonesia \\ Jalan Cempaka Putih Tengan No. 27, RT.11/RW.5, Cemp. Putih Tim., Kec. Cemp. Putih, Kota \\ Jakarta Pusat, Daerah Khusus Ibukota Jakarta 10510 \\ Email: 2016460043@ftumj.ac.id 1 \\ arwityas@yahoo.com 2
}

\begin{abstract}
Kota Baru Parahyangan is an area in the city of Bandung, which is located west of the city of Bandung. This area is an independent city area, expanded from Bandung City and became a satellite city. The new city area of Parahyangan has various facilities such as offices, commercial, residential, recreation, sports, and public facilities. The architecture of the KBP area mostly has a modern tropical style in which the form of adaptation to the cool Bandung city climate, as well as infrastructure that is built in a mature and sustainable manner. This study aims to examine the concept of imageability and permeability in the development of a new city center, Parahyangan, using the Kevin Lynch theory. Imageability is a depiction of the physical quality of an object or area. Permeability is the quality of accessibility and human movement activities in an area. Based on the research analysis, the whole Kota Baru Parahyangan area has good imageability and permeability.
\end{abstract}

Keywords: Imageability, Permeability, Area, City center.

\begin{abstract}
Abstrak: Kawasan Kota Baru Parahyangan merupakan Kawasan di kota Bandung yang terletak di sebelah barat kota Bandung. Kawasan ini merupakan kawasan kota mandiri pemekaran dari kota bandung dan menjadi kota satelit. Kawasan kota baru parahyangan memiliki berbagai fasilitas seperti kantor, komersial, residensial, rekreasi, olahraga, dan fasilitas umum. Arsitektur kawasan KBP sebagian besar memiliki gaya modern tropis yang mana bentuk penyesuaian iklim kota bandung yang sejuk, serta infrastruktur yang dibangun secara matang dan berkelanjutan. Penelitian ini bertujuan untuk mengkaji konsep imageability dan permeability dalam pengembangan pusat kota baru parahyangan dengan menggunakan teori kevin lynch. Imageability merupakan penggambaran kualitas fisik yang dimiliki suatu objek atau Kawasan. Permeability merupakan kualitas aksesibilitas dan aktivitas pergerakan manusia pada suatu kawasan. Berdasarkan analisis penelitian secara keseluruhan kawasan Kota Baru Parahyangan memiliki imageability dan permeability baik.

Kata Kunci: Imageability, Permeability, Kawasan, Pusat kota.
\end{abstract}

\section{Pendahuluan}

Setiap orang yang melakukan wisata berkunjung ke kota-kota di seluruh dunia pasti kurang sempurna apabila tidak menyempatkan untuk jalan-jalan ke pusat kotanya. Pemahaman seseorang tentang suatu kota akan lebih mendalam daripada sekedar kesan visual. Pada suatu kota terdapat banyak arti seperti keindahan, kenangan, pengalaman, harapan, keramaian banyak orang, keragaman bangunan serta drama kehidupan dan kematian, mempengaruhi setiap orang yang mendiami dan memahami suatu kota (Lazuardi, dkk. 2018)(Hantono, 2019). Konsep penataan pusat kota pada kota-kota sebenarnya sudah ada sejak jaman prakolonial. Pusat kota disamping sebagai pusat lalu lintas jalan biasanya dilengkapi juga dengan fasilitas tempat ibadah, taman, dan pusat pemerintahan. Jadi pusat kota sebenarnya berpotensi untuk menjadi salah satu 
identitas bagi kota. Hal ini penting mengingat beberapa kota sedang dilanda krisis identitas baik dalam bidang arsitektur maupun perencanaan kota. Hal ini mungkin disebabkan karena kurang sadarnya masyarakat akan konsep tata ruang kota dimasa lampau. Kajian ini mencoba untuk dipakai sebagai salah satu pertimbangan untuk menghidupkan kembali pusat kota. Pada penelitian ini akan membahas tentang kota baru menurut (Prasetijaningsih, 2017) serta strategi pembangunan kota baru merupakan sebuah kebijakan pendukung pembangunan ekonomi dalam konteks pengembangan wilayah, kebijakan mengatasi masalah perkotaan akibat meningkatnya jumlah penduduk di kota-kota besar.

Kualitas fisik yang diberikan oleh suatu kota dapat menimbulkan suatu image yang cukup kuat dari seorang pengamat. Kualitas ini disebut dengan imageability (imagibilitas) atau kemampuan mendatangkan kesan. Imagibilitas mempunyai hubungan yang sangat erat dengan permeability. Permeability (permeabilitas) merupakan kempampuan seseorang mengakses suatu tempat dengan waktu dan jarak yang telatif dekat dan mudah. Perpaduan antara dua elemen tersebut dapat menghadirkan Kawasan kota yang legibility (legibilitas) atau kemudahan untuk dapat dipamahi/dikenali dan dapat diorganisir menjadi satu pola yang koheren.

Dalam penelitian ini penulis ingin mengkaji mengenai "kajian konsep imageability dan permeability dalam pengembanga Kawasan pusat kota".

Berdasarkan kesimpulan dari pendahulan, maka dapat ditarik suatu rumusan masalah yang akan dibahas adalah bagaimana penerapan teori imageability dan permeability pada kawasan pusat kota Kota Baru Parahyangan, Bandung Barat yang merupakan kota baru. Oleh karena itu, perlu adanya penelitian yang bertujuan untuk membahas Kota Baru Parahyangan dengan konsep imageability dan permeability yang dikemukakan oleh E. Chapman \& K. Lynch.

\section{Tinjauan Pustaka}

\section{Imageability}

Imageability diambil dari kata image dan ability, jika diterjemahkan kedalam Bahasa Indonesia "citra"((Wijaya, dkk., 2019) dan "kemampuan". Dalam kamus besar Bahasa Indonesia "citra" berarti 1) rupa, gambar, gambaran; 2) gambaran yang dimiliki orang banyak mengenai pribadi, perusahaan, organisasi, atau produk; 3) gambaran yang dimiliki orang banyak mengenai pribadi, perusahaan, organisasi, atau produk. Jadi imageability dapat diartikan kemampuan suatu produk untuk menampilkan kesan gambaran visual.

Imageability yang kuat seringkali menjadi tempat yang pertama kali diingat ketika seseorang membayangkan suatu kota atau dengan kata lain menjadi representasi identitas kota. Jika elemen-elemen kota khususnya jalan mudah diingat oleh masyarakat, maka secara umum kota tersebut lebih mudah dipahami atau legible (Chapman \& Lynch, 1962). Sama halnya yang dikemukakan oleh (Tohjjiwa, 2014) Kualitas fisik yang diberikan oleh suatu kota dapat menimbulkan suatu image yang cukup kuat dari seorang pengamat. Kualitas ini disebut dengan imageability (imagibilitas) atau kemampuan mendatangkan kesan bagi pengamatnya.

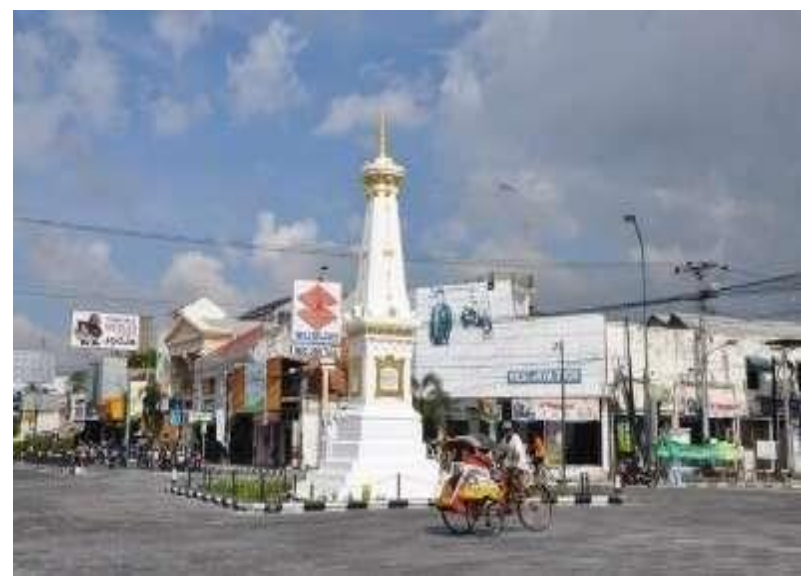

Gambar 1. 1: Image kota dari landmarknya (Sumber: Data Literatur 2020)

Beberapa contoh kota yang memiliki image yang memiliki khas mudah dikenali dan sangat bermakna di hati para pengunjung adalah Yogyakarta. Ketika melihat landmark tugu jogja seseorang langsung mempunyai anggapan bahwa Jogjakarta merupakan kota budaya dengan adat jawa nan kental yang masih terjaga sampai saat ini, kota yang lekat dengan Pendidikan, kota wisata dengan berbagai peristiwa sejarah, kota yang terkenal 
akan kulinernya dengan harga terjangkau. Sehingga dapat dikatakan bahwa kota Yogyakarta memiliki imageability Kawasan kota yang sangat baik, itu artinya juga kota Yogyakarta adalah kota yang legible.

\section{Permeability}

Konsep aksesibilitas merupakan ukuran kemampuan seseorang untuk berpindah dari suatu tempat ke tempat lainnya dengan mudah dalam suatu Kawasan atau wilayah (Raniasta dikutip dari Aqli et al., 2019). Ukuran yang dimaksud dalam hal ini adalah mengenai kedekatan jarak dan waktu yang ditempuh oleh seseorang, serta biaya yang dikeluarkan terjangkau. Suatu tempat memiliki tingkat aksesibilitas yang tinggi apabila jaraknya relative dekat, dengan memakan waktu yang relatif singkat, dandengan biaya yang relatif terjangkau. Aksesibilitas dalam suatu Kawasan begitu penting berperan dalam suatu Kawasan karena untuk mendorong perkembangan Kawasan agar lebih berkembang karena tingkat aksesnya yang mudah dan baik.

Tinggi rendahnya aksesibilitas dapat di ukur dengan jarak, apabila hubungan suatu tempat ke tempat lain berdekatan maka dapat disebut aksesibilitas antara dua tempat tersebut tinggi, dan apabila hubungan suatu tempat ke tempat lainnya berjauhan maka dapat disebut aksesibilitas antara tempat tersebut rendah. (Trolley dan Torton dikutip dari Aqli et al., 2019) mengungkapkan hubungan yang terbentuk antara daerah asal (origin) dan tempat tujuan (destination) adalah komponen penting pembentuk aksesiblitas sehingga aksesibilitas dianggap sebagai kelancaran seseorang mencapai lokasi tertentu.

\section{Kawasan}

Kawasan merupakan tempat dengan ciri-ciri memiliki kegiatan manusia berdasarkan kebutuhannya secara khusus, dan apabila suatu tempat tersebut memiliki ciri ataupun identitas maka akan lebih mudah untuk dicari dan dihuni untuk membantu manusia dalam segala hal yang berhubungan dengan kebutuhan hidup dan kegiatan sehari-hari. Kawasan adalah bagian dari beberapa wilayah yang berada di sebuah kota. Dan secara morfologinya terbagi menjadi Kawasan industri, Kawasan perkantoran, Kawasan pemukiman, Kawasan pemerintahan, Kawasan area hijau, Kawasan area perdagangan dan Kawasan wisata (Purwantiasning et al., 2013).

\section{Kota}

Sebuah kota adalah suatu permukiman yang relatif besar, padat, dan permanen. Terdiri dari kelompok individu-individu yang heterogen dari segi sosial. (Rapoport, Amos dikutip dari Markus, 1999)

Menurut (Rapoport, Amos dikutip dari Markus, 1999) yang menggunakan 10 kriteria secara lebih spesifik untuk merumuskan kota sebagai berikut :

1. Ukuran dan jumlah penduduknya yang besar terhadap massa dan tempat;

2. Bersifat permanen;

3. Kepadatan minimum terhadap massa dan tempat;

4. Struktur dan tata ruang perkotaan seperti yang ditunnjukan oleh jalur jalan dan ruang-ruang perkotaan yang nyata;

5. Tempat dimana masyarakat tinggal dan bekerja;

6. Fungsi perkotaan minimum yang diperinci, yang meliputi sebuah pasar, sebuah pusat administrative atau pemerintahan, sebuah pusat militer, sebuah pusat keagamaan, atau sebuah pusat aktivitas intelektual Bersama dengan kelembagaan yang sama;

7. Heterogenitas dan pembedaan yang bersifat hierarkis pada masyarakat;

8. Pusat ekonomi perkotaan yang menghubungkan sebuah daerah pertanian di tepi kota dan memproses bahan mentah untuk pemasaran yang lebih luas;

9. Pusat pelayanan (services) bagi daerah-daerah lingkungan setempat;

10. Pusat penyebaran, memiliki suatu filsafah hidup perkotaan pada massa dan tempat itu (Rapoport, Amos dikutip dari Markus, 1999).

Menurut (Chapman \& Lynch, 1962) memfokuskan pada kebutahan pembentukan karakter kota yang dimulai dengan persepsi lingkungan, tanda pengenal dan kemudian citra kota. Oleh karena itu (Chapman \& Lynch, 1962) menekankan pada argumentasi adanya 8 kriteria terpadu dalam menciptakan bentuk yang kota adalah: 
1. Singularity yaitu adanya batasan yang jelas baik antar kawasannya maupun antara kawasan perkotaan dan perdesaan sekitarnya

2. Continuity yaitu kaitan fungsional antara satu tempat dan tempat yang lain secara efektif dan efisien.

3. Simplicity yaitu kejelasan dan keterpaduan morfologi dan tipologinya.

4. Dominance yaitu memiliki bagian kota yang mempunyai karakter khusus dan penting..

5. Clarity of joint yaitu bagian strategis yang mampu berhubungan dengan sisi yang lain.

6. Visual scope yaitu tempat terbuka atau tinggi yang dapat memandang secara bebas dan lepas ke semua penjuru kota.

7. Directional differentiation yaitu beragam-beragam bentukan fisik yang diatur secara harmonis.

8. Motion awareness yaitu kemampuan menggerakan emosional yaitu perasaan nyaman dan dinamis.

\section{Metode Penelitian}

Dalam metode jurnal ini, penulis menggunakan jenis penelitian deskriptif kualitatif dengan dimana setiap aspek-aspek dalam penelitian ini akan dideskripsikan dan diidentifikasikan berdasarkan pada gambaran situasi mengenai fakta-fakta yang ada. Pada penelitian ini peneliti menggunakan data hasil dari studi literatur dan observasi secara tidak langsung untuk memperoleh hasil penelitian.

Penelitian dilakukan di lokasi Kota Baru Parahyangan yang terletak di sebelah barat dari kota Bandung.

\section{Studi kasus : Kota Baru Parahyangan, Bandung, Jawa Barat}

Kota Baru Parahyangan merupakan Kota mandiri pengembangan Kawasan dari kota Bandung, Kota KBP terletak di sebelah barat dari kota Bandung. Belajar dari BSD city PT. Balaputera Intiland memiliki impian untuk menciptakan kota baru yang lebih baik dan menjadi kota satelit bagi bandung. Kawasan kota parahyangan sendiri memiliki citra tinggi bagi masyarakat karena terdapat berbagai fasilitas yang mewah.

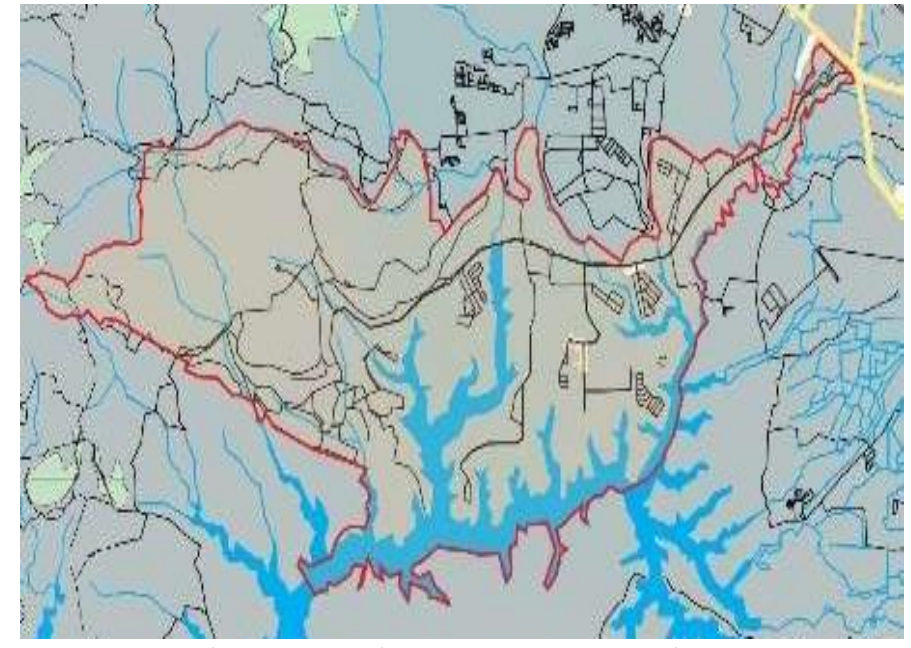

Gambar 2. 1: Lokasi Kota Baru Parahyangan

(Sumber: Diolah dari berbagain sumber, 2020)

\section{Hasil dan Pembahasan}

\subsection{Permeability}

Permeability adalah teori yang dikembangkan oleh (Chapman \& Lynch, 1962) membahas tentang aksesibilitas pencapaian suatu ruang, ruang dapat diartikan sebagai proses untuk mencapai suatu ruang baik ruang dari dalam maupun ruang dari luar. Konsep permeability ini di implementasikan pada Kota Baru Parahyangan.

Kawasan Kota Baru Parahyangan merupakan Kawasan dengan beragam fungsi yang menjadikannya banyak pergerakan aktivitas. Menurut (Chapman \& Lynch, 1962) suatu Kawasan dapat dinilai permeabilitasnya berdasarkan beberapa aspek yaitu diantaranya :

1. Blok Bangunan

Blok bangunan pada Kawasan KBP umumnya memiliki blok yang besar, blok memiliki bentuk tidak beraturan. Blok yang tercipta masih belum banyak hanya beberapa blok dalam Kawasan, blok yang tercipta 
merupakan hasil dari pembuatan jalur sirkulasi yang terencana. Pada Kawasan KBP dilakukan pengujian aksesibilitas pada suatu tempat titik merah berada pada tengah Kawasan yang Sebagian besar merupakan areal perumahan menuju titik kuning merupakan fasilitas sosial masjid Al-Irsyad dapat melalui jalur pada gambar 3.1 yaitu melalui jalur jalan guru gantangan lurus melalui jalan gelap nyawang belok kanan menuju jalan raya parahyangan. Selanjutnya pengujian titik kuning menuju titik hijau dapat menggunakan jalur Jalan raya parahyangan, belok kiri 2 kali lalu menuju jalur Cikande Cilesang.

Berdasarkan pengujian yang elah dilakukan, maka dapat diambil kesimpulan bahwa bentuk blok yang memanjang akan terasa sedikit sulit atau memiliki jarak tempuh yang jauh untuk mencapai titik ke titik lainnya. Pencapaian akan terasa lebih mudah bila jalur dibuat alternatif lain yang dapat merangkul seluruh Kawasan dengan radius yang dekat.

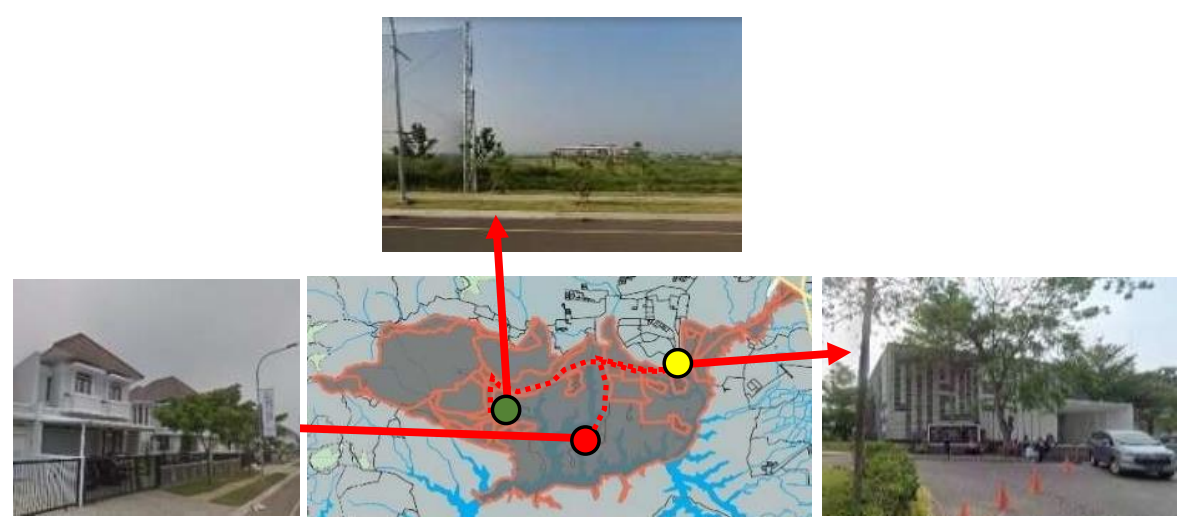

Gambar 3. 1 : Pengujian Titik merah ke kuning ke hijau

(Sumber: Data Peneliti 2020)

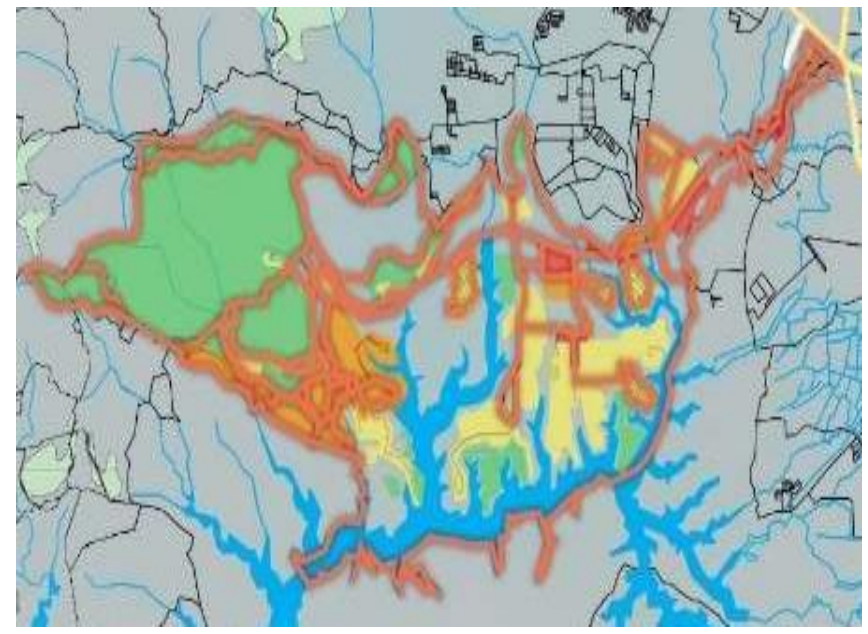

Gambar 3. 2 : Permeability Berdasarkan Fungsi Bangunan

(Sumber: Data Peneliti 2020)

Kawasan Kota Baru Parahyangan memiliki bangunan dengan fasad yang berbeda-beda setiap pertokoan, perkantoran, perumahan dan area komersial menampilkan ciri khas baik khas lokal maupun budayanya. Untuk gaya arsitekturnya pada Kawasan KBP mengusung gaya modern yang menyesuaikan iklim tropis namun secara keseluruhan kawasannya belum memiliki arsitektural yang kontekstual dengan lingkungannya. Kawasan yang memiliki fungsi yang bervariasi dapat meningkatkan permeability suatu kawasan atau lingkungan (Yavuz, A, dan Kuloğlu, 2014). 


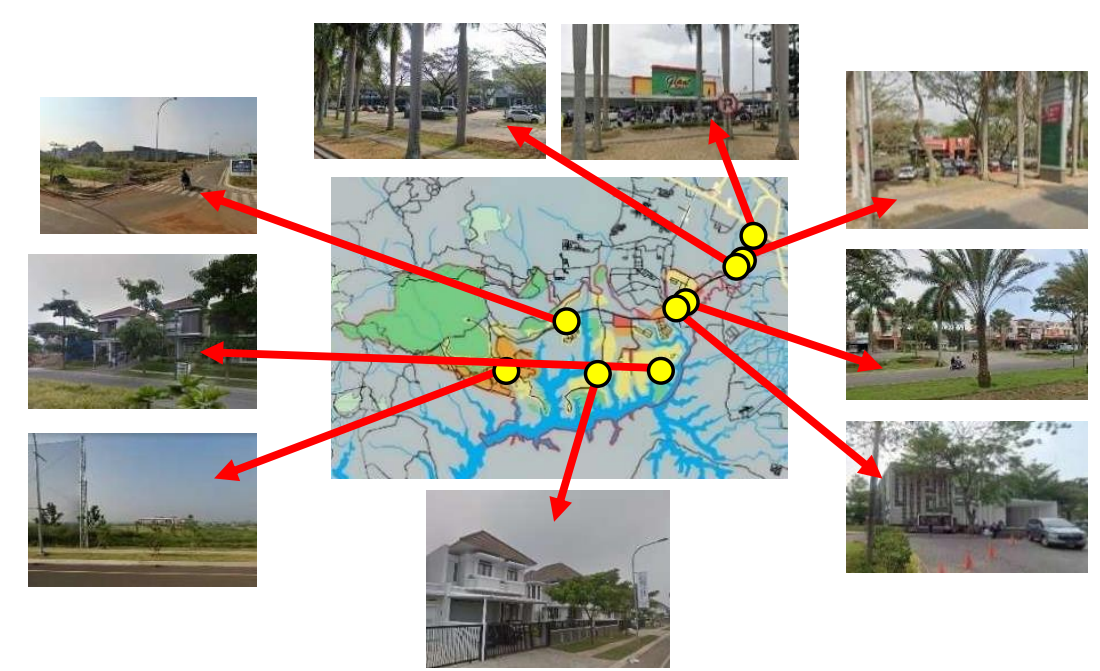

Gambar 3. 3 : Blok Bangunan KBP

(Sumber: Google Street View, n.d. 2020)

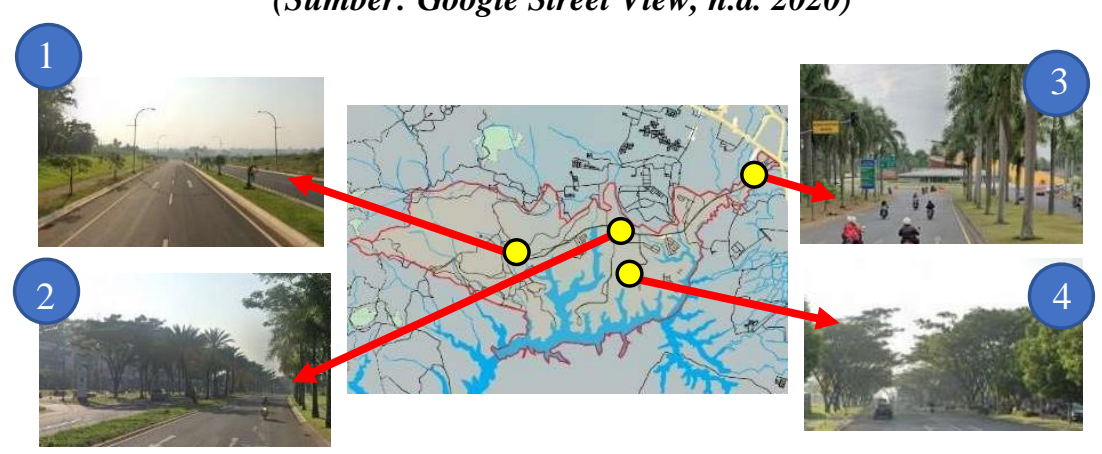

Gambar 3. 4 : Jalur Jalan KBP

2. Lebar jalur

(Sumber: Google Street View, n.d. 2020)

Lebar jalur jalan Kota Baru Parahyangan memiliki lebar yang besar yang memungkinkan memudahkan dalam mencapai suatu tempat pada kawasan kota. Apabila jalur sirkulasi jalan sebuah kawasan itu lebar atau besar maka permeabilitas pada kawasan tersebut juga semakin meningkat (Silavi T, Farshad H, Christophe C, 2017).
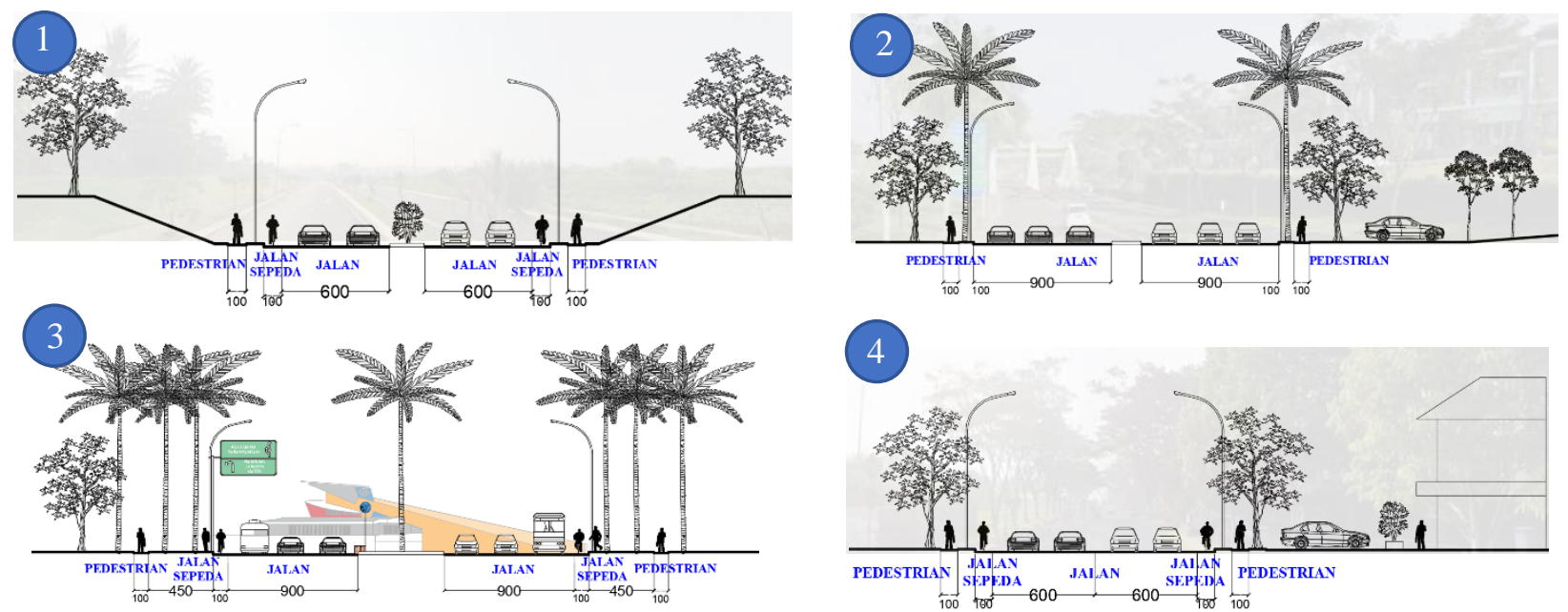

Gambar 3. 5 : (1) Lebar jalur Parahyangan St; (2) Lebar jalur Parahyangan St; (3) Lebar jalur Parahyangan St; (4) Lebar jalur Niaga Kulon

(Sumber: Data Peneliti 2020) 
Jalur pada titik 1 merupakan jalur jalan raya parahyangan yang berada di bagian barat Kawasan KBP. Jalan ini memiliki lebar 6 meter dengan 2 lajur dan memiliki 2 lajur, jalur ini memiliki fasilitas untuk pesepeda dengan lebar 1 meter yang terletak di sebelah kiri jalur jalan. Antara jalur sepeda dan pejalan kaki terdapat ruang untuk tanaman penghijauan. Di samping trotoar juga ditanami pohon yang rindang.

Jalur pada titik 2 merupakan jalur jalan raya parahyangan yang berada di bagian tengah Kawasan. Jalan ini memiliki lebar 9 meter dengan 3 lajur dan 2 jalur. Jalan ini terasa lebar untuk aksesibilitas dalam Kawasan. Di samping jalur terdapat pohon palm, lampu jalan, dan pedestrian dengan lebar 1 meter. Pada sebelah kiri terdapat pertokoan.

Jalur pada titik 3 merupakan jalur jalan raya parahyangan yang berada di bagian timur Kawasan. Jalur sirkulasi ini merupakan jalur utama untuk memasuki Kawasan KBP yang disambut langsung dengan landmark Kawasan Kota baru parahyangan. Jalur ini memiliki lebar 9 meter dengan 3 lajur dan 2 jalur, memiliki fasilitas jalur pesepeda dengan lebar 1 meter disampingnya terdapat jalur pedestrian dengan lebar 1 meter, transisi antara jalur pesepeda dengan jalur pejalan kaki lebar dengan 4,5 meter digunakan untuk pohon palm yang memberikan kesan mewah dan dapat menyajikan pandangan yang luas.

Jalur pada titik 4 merupakan jalur jalan raya parahyangan yang berada di bagian tengah menuju timur Kawasan yang merupakan areal perumahan dan pertokoan. Jalur ini memiliki lebar 6 meter dengan 2 lajur dan 2 jalur. Memiliki fasilitas untuk bersepeda dengan lebar 1 meter dan trotoar untuk pejalan kaki dengan lebar 1 meter.pada samping kanan terdapat pertokoan untuk berbelanja kebutuhan sebelum memasuki areal perumahan.

\section{Hubungan jalur Sirkulasi}

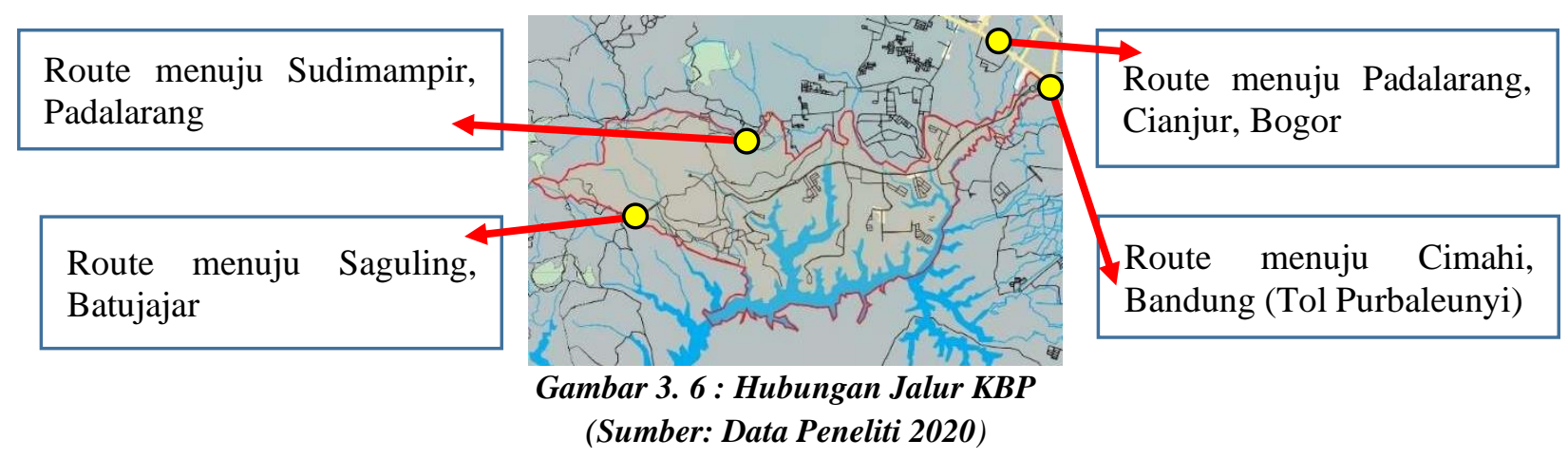

Jalur sirkulasi merupakan jalur yang digunakan sebagai ruang pergerakan, baik digunakan untuk pergerakan manusia maupun kendaraan (Purwantiasning \& Setyoningrum, 2020). Kawasan kota baru parahyangan memiliki jalur yang tidak banyak untuk akses ke dalam kawasan. kawasan KBP belum terdapat moda transportasi masal yang dapat mengakses kedalam kawasan namun secara rambu-rambu sudah tertera dengan jelas. Jalur yang umumnya digunakan yaitu dari jalur jalan padalarang sedangkan apabila pengunjung dari Jakarta ataupun Bandung dapat menggunakan fasilitas jalur tol. Tol yang dapat digunakan padalarang cileunyi. Untuk akses dalam kawasannya sendiri jalur yang sering digunakan yaitu jalur jalan raya parahyangan. (Hartanti \& Trisakti, 2018) mengungkapkan hubungan saling mempengaruhi antara familiaritas, keunikan dan legibility atau keterbacaan. Faktor keunikan akan memperkuat keterbacaan koridor jalan dan Ketika suatu koridor itu lebih mudah dikenali, maka seseorang akan cenderung memilih atau menyukai untuk melalui jalan tersebut.

Secara keseluruhan Kawasan kota baru parahyangan memiliki kualitas permeability yang baik. Kawasan KBP untuk saat ini hanya nyaman digunakan untuk berhuni karena secara iklim sejuk dan pemandangan yang indah menuju danau. kawasan ini cocok untuk mengisi waktu keluarga pada saat akhir pekan ataupun seseorang yang bekerja di kota bandung pulang pergi menuju Kawasan parahyangan. 


\subsection{Imageability}

Imageablitity adalah teori yang dicetuskan oleh Kevin lynch yang membahas tentang Gambaran fisik suatu objek kota dapat memimbulkan pengaruh besar dalam image kota yang dapat diterima oleh seseorang. Kualitas fisik yang dihasilkan oleh suatu Kawasan ini di buat dalam 5 elemen diantaranya Path, Edge, District, Node, dan Landmark (Lynch 1980). Lalu elemen ini dierapkan pada Kawasan Kota Baru Parahyangan Bandung.

Kawasan Kowloon Hongkong merupakan Kawasan padat dengan aktivitas dan mempunyai mobilitas tinggi, pusat perdagangan, hotel, rekreasi, tempat bersejarah dan Kawasan wisatawan. Lima elemen berdasarkan teori kevin lynch diimplementasikan sebagai berikut :

\section{1. $\operatorname{Jalur}($ Path $)$}

Jalur sirkulasi yang mengelilingi kawasan kota disebut dengan path (Chapman \& Lynch, 1962). Path dapat berupa jalan raya, jalur transit, rel kereta, kanal, jalur pejalan kaki. Kalur pejalan kaki atau trotoar biasanya terdapat pada samping jalan, kanal, rel kereta ataupun jalur lainnya. Jalur pejalan kaki memiliki ukuran yang bervariasi sesuai standart atau kebutuhannya. Jalur pejalan kaki pada Kota Baru parahyangan sebagai berikut.

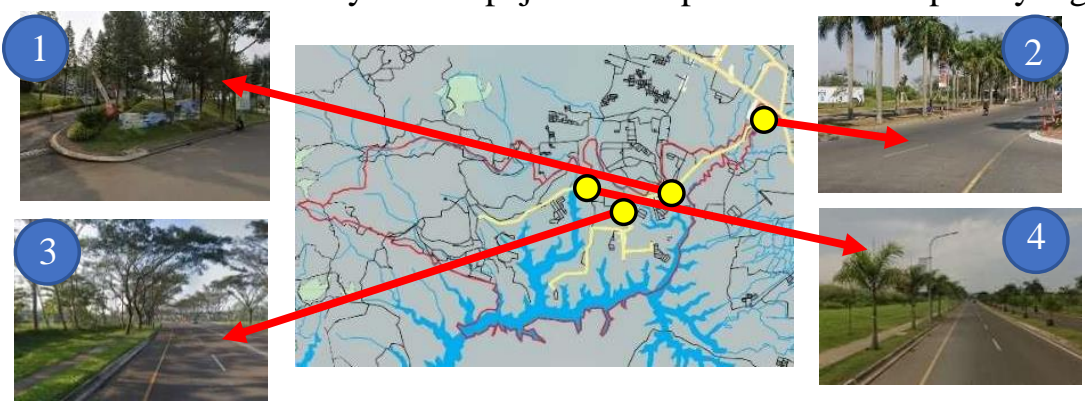

Gambar 3. 7 : Jalur Pejalan Kaki

(Sumber: Google Street View, n.d. 2020)
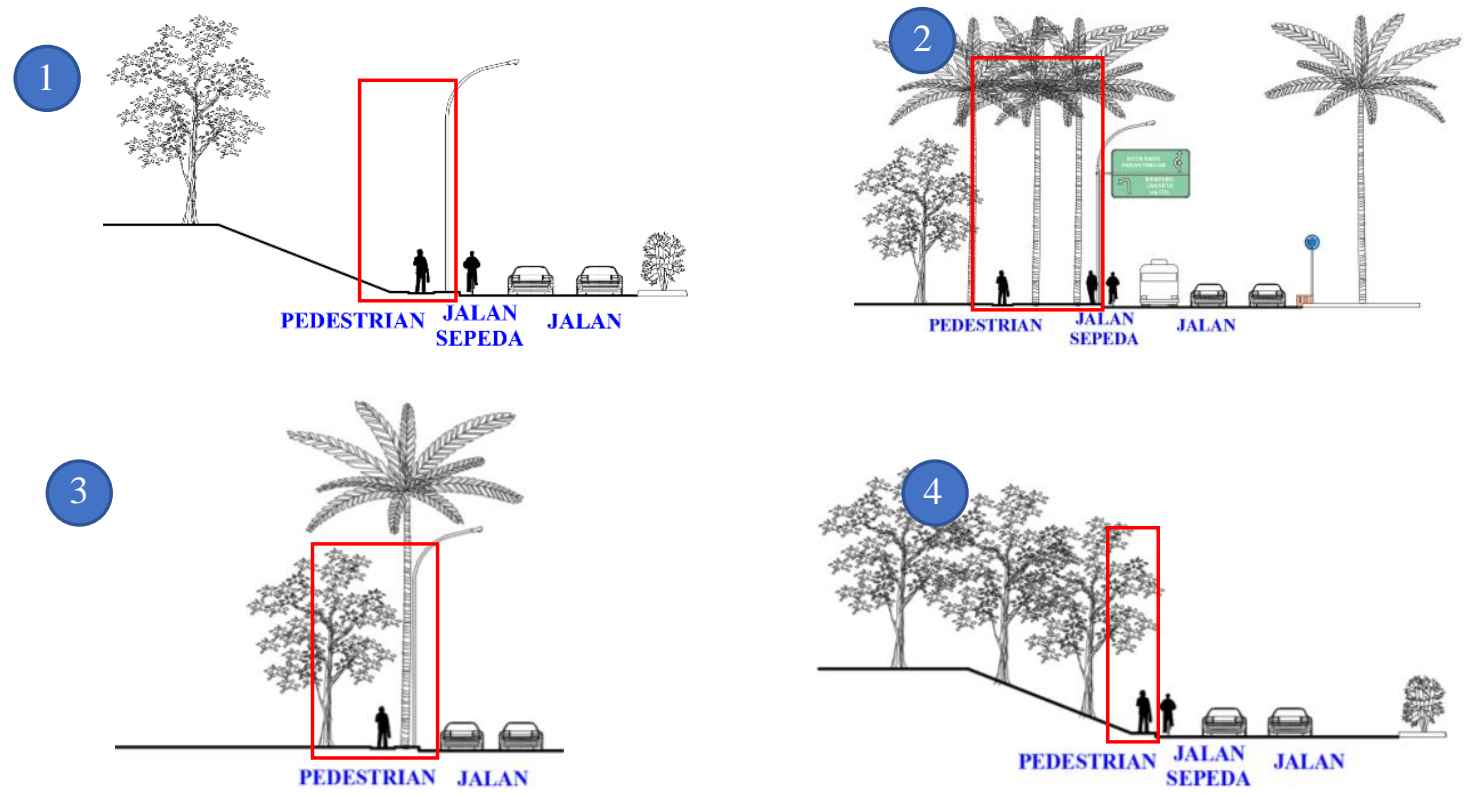

\section{Gambar 3. 8 : Potongan Jalur Pejalan Kaki}

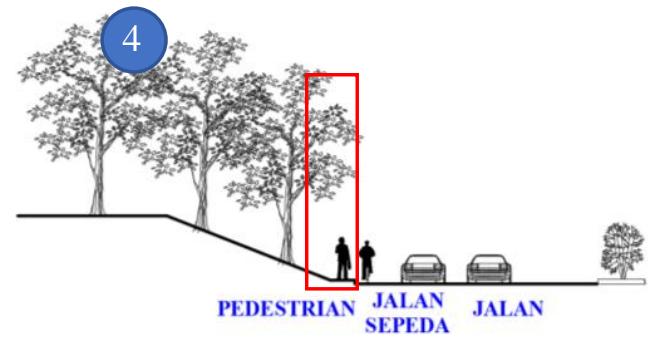

(Sumber:Data Peneliti 2020)

Jalur pejalan kaki pada kawasan KBP memiliki standart yang baik karena pada setiap jalur trotoar memiliki posisi yang tidak berbatasan langsung dengan jalan melainkan ada transisi berupa tanaman atau pepohonan yang membuat pejalan kaki dapat merasa aman ketika berjalan pada trotoar. Jalur pejalan kaki tersebut terdapat pada jalan arteri atau jalan utama. Material yang digunakan pada trotoar dengan beton yang membuat nyaman untuk berjalan kaki. 


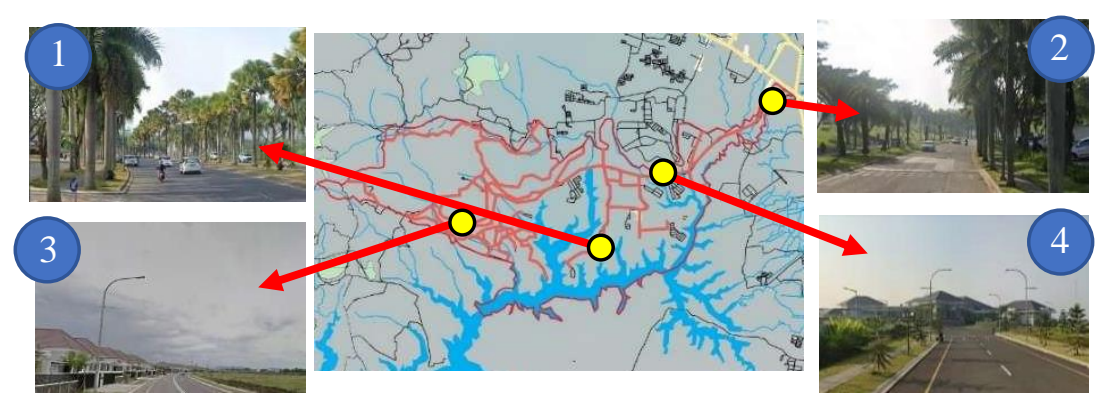

Gambar 3. 9 : Jalur Jalan Raya

(Sumber: Google Street View, n.d. 2020)
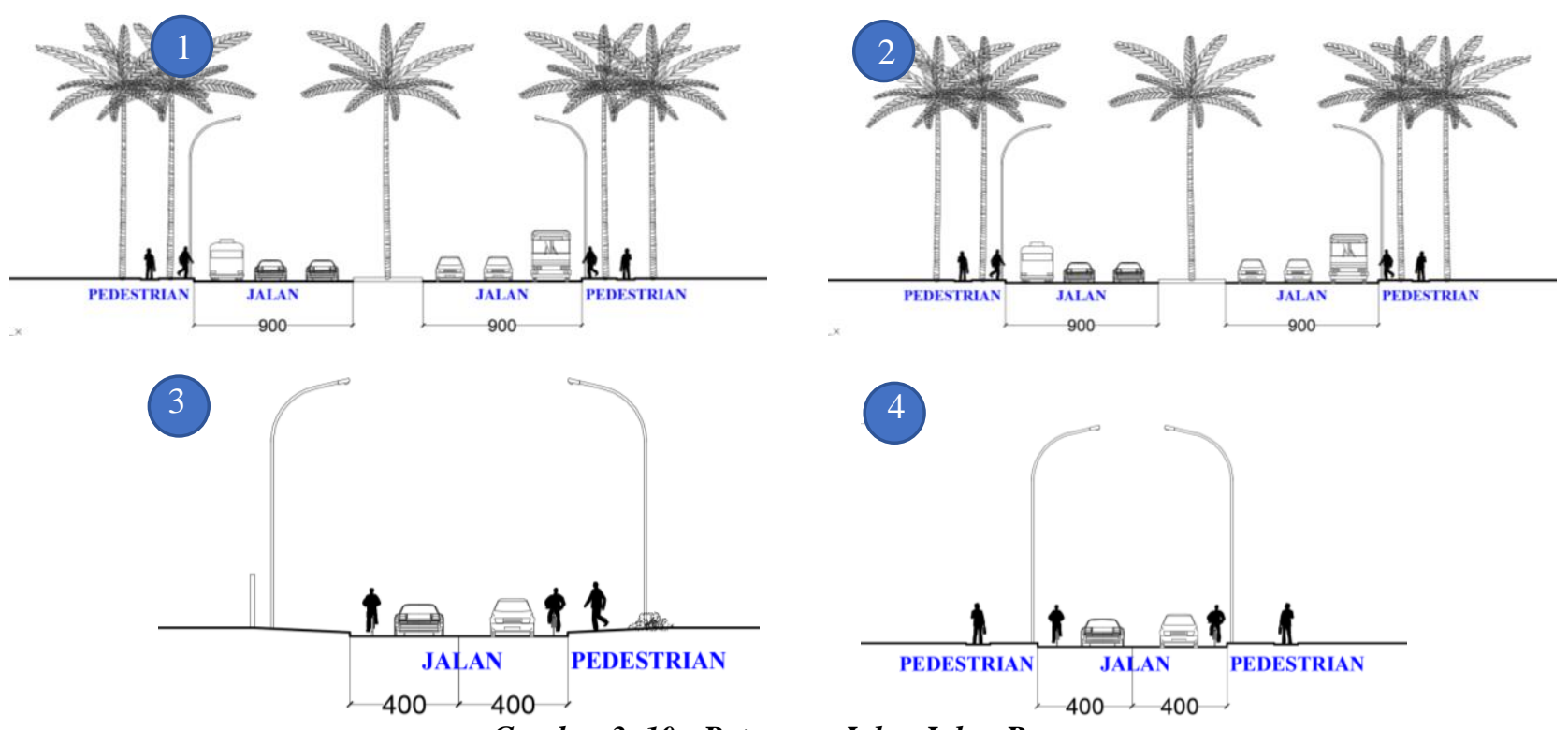

(Sumber: Data Peneliti 2020)

Jalur jalan raya pada kawasan KBP cenderung berbentuk linier kondisi ini dipengaruhi oleh keadaan geografis Kawasan yang berdekatan dengan danau sebagai penampungan air ketika hujan.

\section{Persimpangan (Node)}

Persimpangan Jalan atau simpul merupakan sebuah titik pertemuan jalur atau path. path yang saling bertemu disebut dengan node atau biasa disebut dengan pertigaaan, perempatan atau simpang lima.

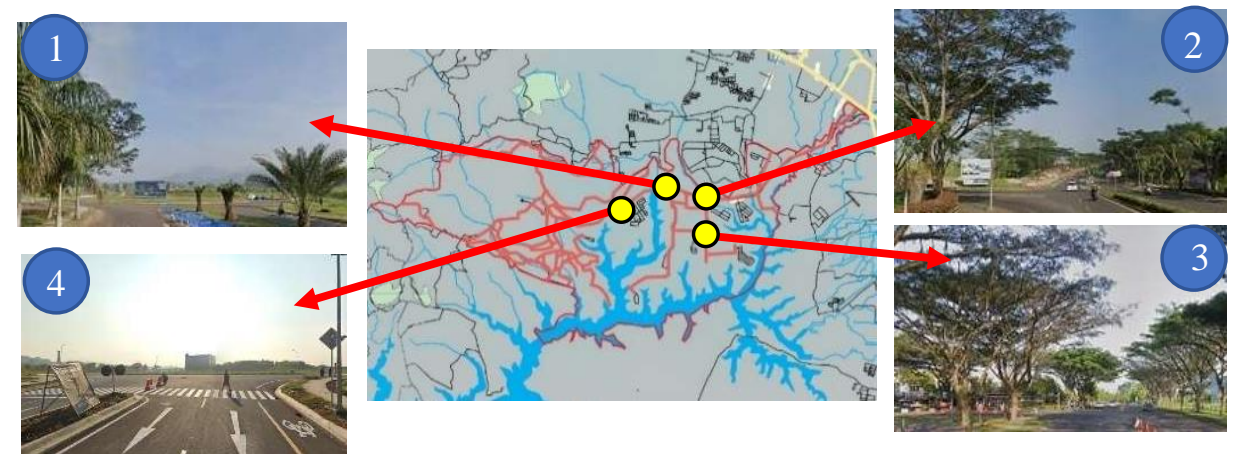

Gambar 3. 11 : Node Kawasan KBP

(Sumber: Google Street View, n.d. 2020) 

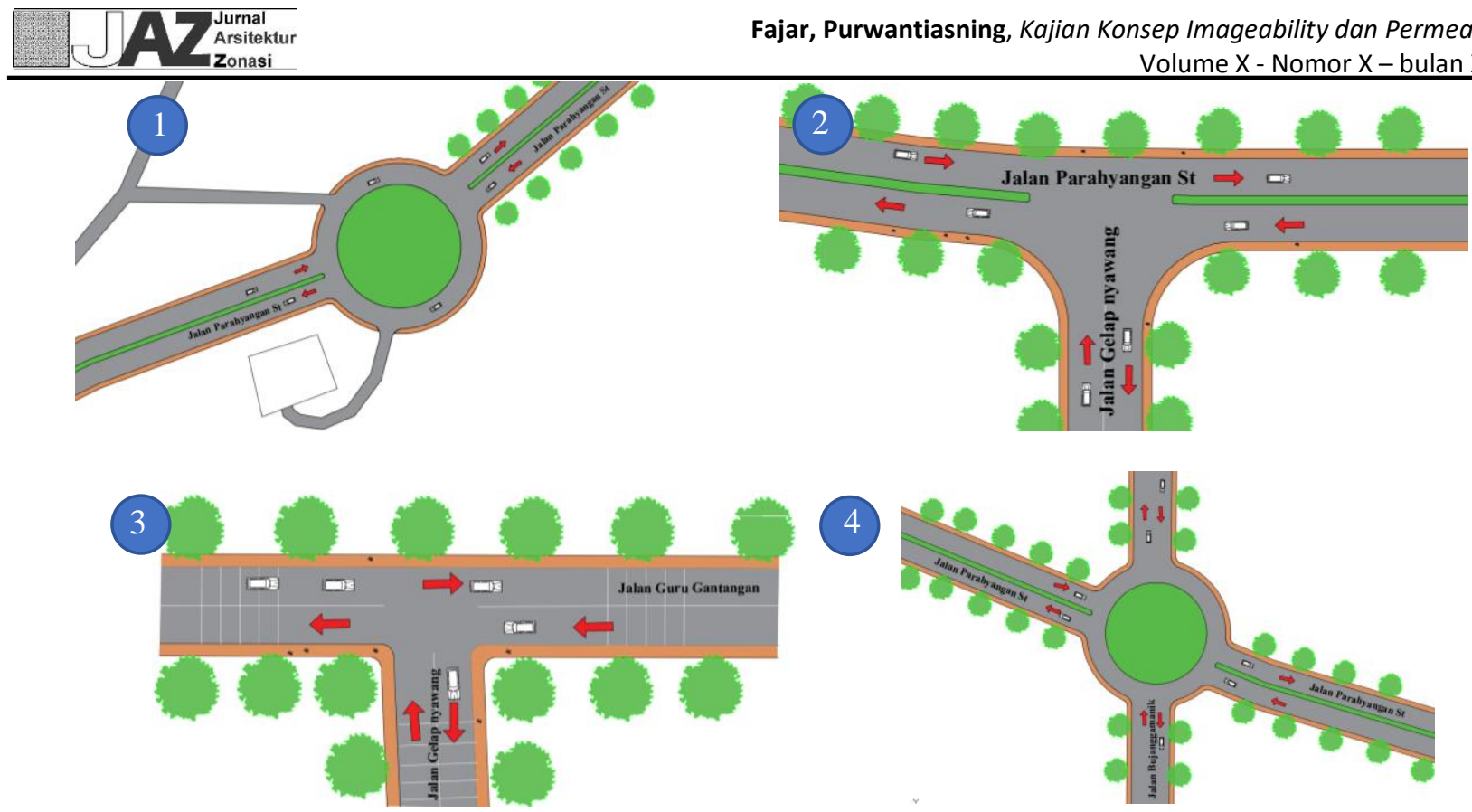

Gambar 3. 12 : Node Kawasan KBP

(Sumber: Data Peneliti 2020)

Persimpangan jalan pada Kawasan KBP tidak terlalu banyak, pada jalur jalan raya parahyangan Kawasan KBP ada beberapa titik persimpangan yang dibuat menjadi bundaran untuk menciptakan persimpangan tanpa lampu merah sehingga pengguna jalan dapat leluasa bersirkulasi pada Kawasan parahyangan.

\section{Tengaran (Landmark)}

Landmark atau tengaran merupakan suatu gambaran kota yanng mencolok dan bertempat pada tempat yang strategis mempunyai makna dan arti penting untuk kotanya, sehingga membuat ciri khas dan jati diri kota tersebut. Fungsi landmark secara umum adalah sebagai orientasi (titik reverensi) kota, sebagai struktur aktivitas kota, sebagai pengarah rute pergerakan, sebagai tanda atau ciri suatu kota (Purwantiasning et al., 2013).

Landmark Kawasan kota baru parahyangan terletak berdekatan dengan gerbang menuju Kawasan, landmark ini bukan hanya sebagai patung ataupun tengaran melainkan memiliki fungsi sebagai penanda waktu menggunakan cahaya matahari yang dapat menunjukan jam, berdasarkan (Kota Baru Parahyangan, n.d. 2020) Gerbang KBP memakai konsep Tata Surya. selain itu landmark dinamakan Puspa Iptek Sundial yang merupakan wahana Pendidikan yang diresmikan pada tanggal 11 mei 2002 yang bertepatan dengan hari Pendidikan nasional.

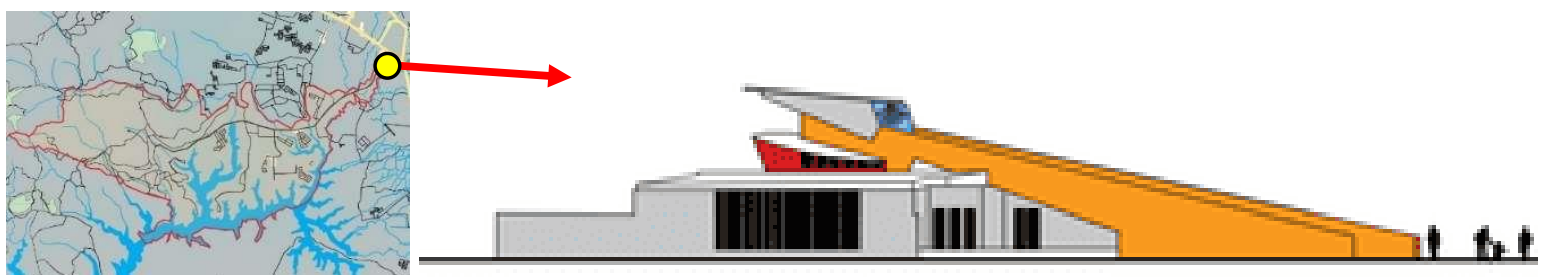

Gambar 3. 13 : Landmark Kawasan KBP

(Sumber: Data Peneliti 2020)

Keberadaan puspa iptek sundial ini sebagai perwujudan kota baru parahyangan sebagai kota mandiri yang berwawasan Pendidikan, dan untuk mendorong masyarakat akan semakin tingginya kepedulian terhadap dunia sains dan teknologi. Jam matahari vertical dan horizontal ini merupakan jam matahari terbesar di Indonesia sehingga mendapatkan rekor MURI pada tahun 2002.

\section{Distrik (District)}

Distrik merupakan sebuah kawasan yang terletak dalam suatu kota. Menurut (Chapman \& Lynch, 1962) mengungkapkan distrik merupakan kawasan kota yang bersifat dua dimensi dimana di dalamnya terdapat 
bentuk, pola, dan wujud. Pendapat lain menurut (Noviana, 2012) Distrik merupakan suatu kawasan didalam suatu kota yang memiliki karakter khusus yang mudah dikenal.
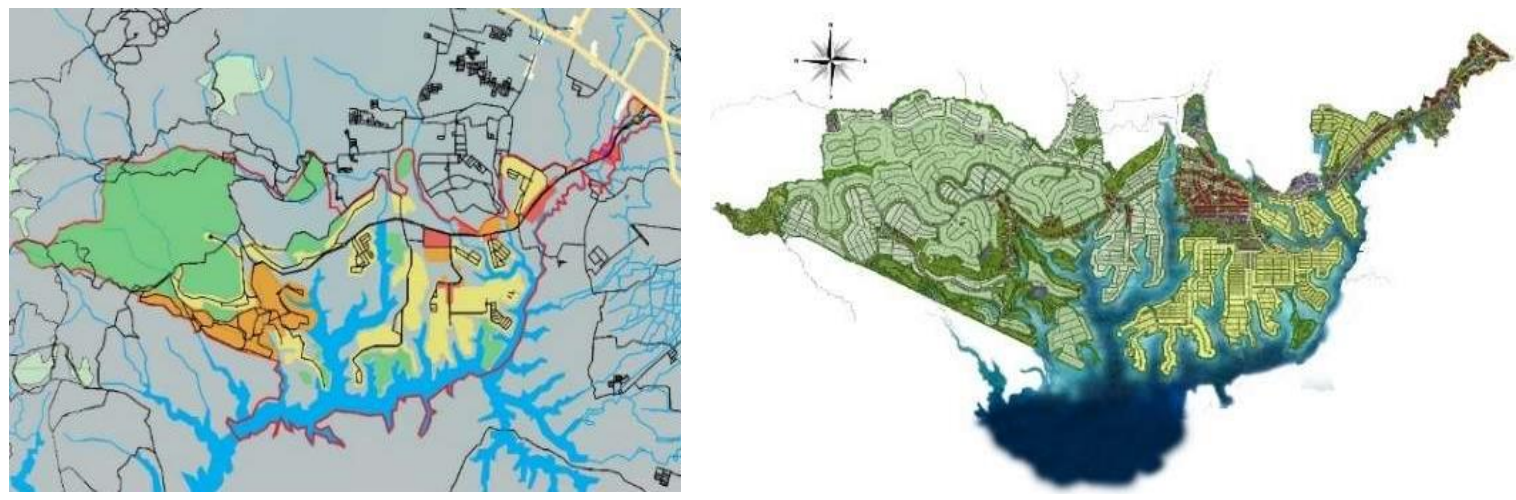

Gambar 3. 14 : Distrik Kawasan KBP

(Sumber: Kota Baru Parahyangan Kota Mandiri Berwawasan Pendidikan, n.d. 2020)

Distrik pada Kawasan kota baru parahyangan memiliki beragan fungsi yakni permukiman, Pendidikan, perkantoran rekreasi, dan komersial. Kawasan kota baru parahyangan ini masih dalam pengembangan kawasan yang akan menjadi kota mandiri seperti Kawasan BSD city Tangerang.

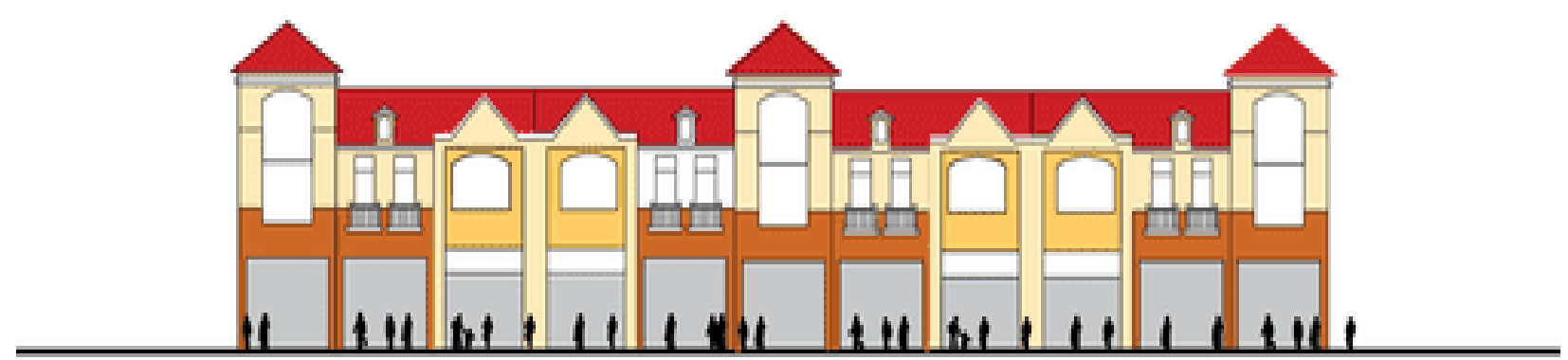

Gambar 3. 15 : Blok Distrik KBP

(Sumber: Data Peneliti 2020)

Kawasan Parahyangan pada blok-bloknya Sebagian besar memiliki tipe bagian depan berupa areal komersial dan dibelakangnya areal perumahan hal ini untuk memfasilitasi dan mempermudah bagi penghuni kawasan parahyangan, untuk gaya arsitekturnya pun beragam namun sebagian besar merupakan gaya arsitektur tropism modern.

\section{Batas Wilayah $(E d g e)$}

Batas wilayah atau Edge merupakan batas suatu Kawasan. Pada kawasan Kota Baru parahyangan terdapat batasan wilayah yang jelas. Edge berada pada batas antara dua kawasan tertentu dan berfungsi sebagai pemutus linear, misalnya pantai, tembok, batasan antara lintasan kereta api, topografi, dan sebagainya (Wahab, Sitti R,. Rundonuwu, Dwight., 2018).

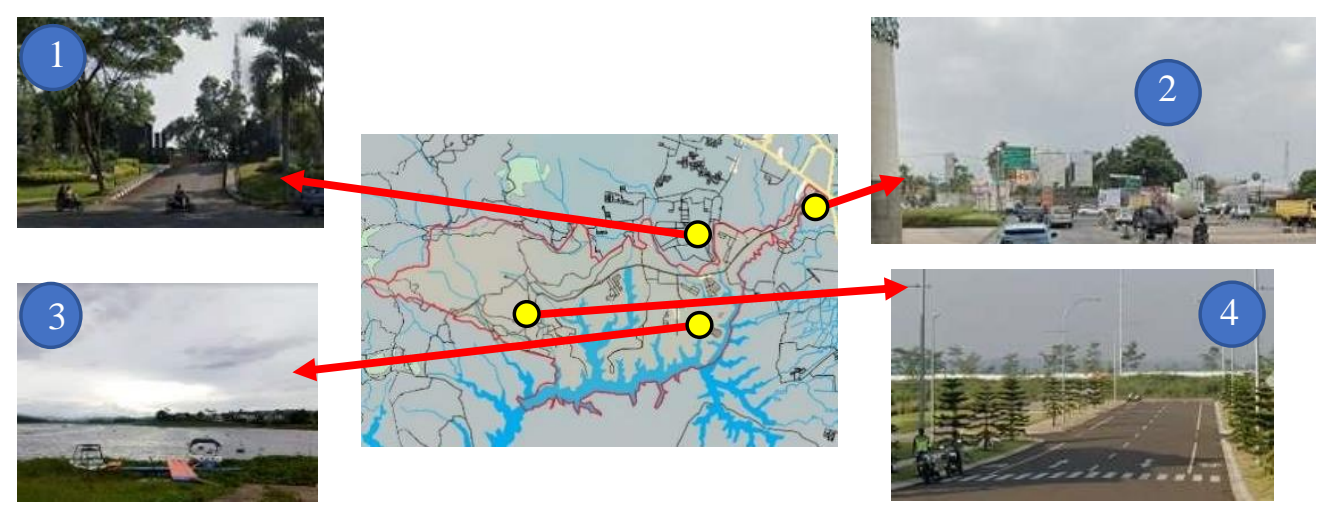

Gambar 3. 16 : Batas Wilayah KBP

(Sumber: Google Street View, n.d. 2020) 

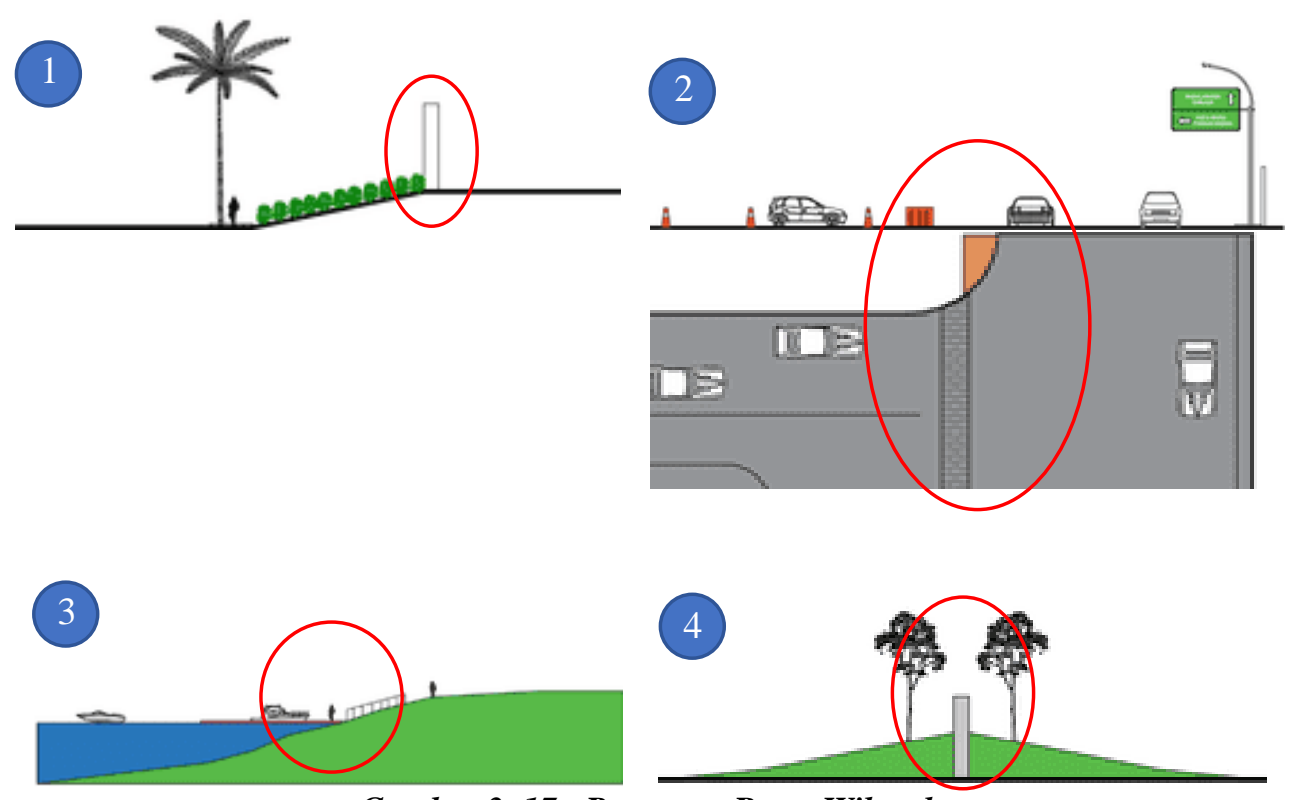

Gambar 3. 17 : Potongan Batas Wilayah

(Sumber: Pribadi 2020)

Batasan wilayah kota baru parahyangan pada bagian utara berbatasan dengan Pusat Pedidikan Kavaleri (Pusdikkav). Batas pada bagian timur berbatasan dengan jalan raya padalarang yang merupakan gerbang menuju Kawasan kota baru parahyangan. Batasan wilayah pada bagian selatan terdapat pada danau, dan batasan wilayah yang terletak di bagian barat berbatasan dengan lapangan golf, batasan wilayah ini terbuat dari benteng yang cukup tinggi jika seseorang sedang berapa di gerbang menuju tempat golf maka batasan tersebut akan jelas terlihat.

\section{Kesimpulan}

Imageability merupakan citra yang dapat dirasakan secara visual dan kualitas fisik yang terdapat pada suatu Kawasan atau tempat. Imageability ini berkaitan erat dengan permeability. Permeability merupakan aksesibilitas pencapaian suatu ruang, ruang dapat diartikan sebagai proses untuk mencapai suatu ruang baik ruang dari dalam maupun ruang dari luar kawasan. Imageability dan permeability memberikan kejelasan pada seseorang yang pada suatu Kawasan sehingga memberikan kemudahan dan cepat dalam aktivitas pada suatu Kawasan. Perpaduan antara elemen Imageability dan permeability akan menghadirkan Kawasan kota yang legibility atau dapat diartikan kemudahan untuk dapat dipahami atau dikenali dan terorganisir menjadi suatu pola koheren atau memiliki keterkaitan antara bagian yang satu dengan bagian yang lainnya, sehingga memiliki kesatuan makna yang utuh.

Kawasan kota baru Parahyangan merupakan kota baru yang terdapat di bandung barat, provinsi jawa barat. Kawasan ini masih dalam tahap pembangunan berkelanjutan yang ingin menjadi kota mandiri seperti Kawasan BSD city. Kawasan ini memiliki fasilitas perkantoran, perumahan, komersial, dan rekreasi namun yang paling menonjol adalah blok perumahan. Kawasan kota baru parahyangan memiliki path dan node yang jelas dan lebar memudahkan pergerakan dalam bermobilitas. Blok distrik yang tidak terlalu banyak dan dengan radius yang jauh membuat Kawasan belum terdapat banyak bangunan dan masih banyak areal lahan kosong. Landmark Kawasan kota baru parahyangan sangat baik karena berfungsi sebagai jam matahari dan tempat pendidikan sains dan teknologi. Batas wilayah atau edge Kawasan ini ditandai dengan jelas seperti pembuatan benteng pada batas dan berbatasan dengan jalan raya. Secara keseluruhan Kawasan kota baru parahyangan sudah memiliki imageability dan permeability yang baik.

\section{Referensi}

Aqli, W., Mauliani, L., \& Anisa. (2019). Permeabilitas kawasan jalan mh. thamrin terhadap akses pejalan kaki menuju stasiun mrt bundaran hi jakarta. Arsitektur, 18(1), 75-84.

Chapman, E. H., \& Lynch, K. (1962). The Image of the City. In The Journal of Aesthetics and Art Criticism (Vol. 21, Issue 1). https://doi.org/10.2307/427643

Google Street View. (n.d.). Retrieved May 5, 2020, from https://www.google.com/maps 
Hantono, D., Butudoka, Z., Prakoso, A. A., \& Yulisaksono, D. (2019). Adaptasi Seting Ruang Pasar Jiung Terhadap Kehadiran Pasar Temporer Di Jalan Kemayoran Gempol Barat Jakarta. Jurnal Arsitektur Zonasi, 2(2), 75. https://doi.org/10.17509/jaz.v2i2.13628

Hartanti, N. B., \& Trisakti, U. (2018). KORIDOR JALAN DAN LEGIBILITY KOTA BOGOR The Influence of Street Functional Arrangement to the Imageability of Street Corridors and the Legibility of Bogor City.

Kota Baru parahyangan Kota Mandiri Berwawasan Pendidikan. (n.d.). Retrieved May 10, 2020, from www.kotabaruparahyangan.com

Lazuardi, Muhamad J., Astuti, Winny., \& Rini, E. F. (2018). Analisis Citra Kawasan Mangkunegaran berdasarkan Penilaian Stakeholder dengan Konsep Legibility Analysis of Mangkunegaran Area Imagery based on Stakeholder Assesment with Legibility Concept. 13.

Markus, Z. (1999). Perancangan Kota Secara Terpadu (2006th ed.). PT Kansius.

Noviana, M. (2012). Kajian elemen pembentuk citra kawasan jalan kusuma bangsa samarinda. Jurnal Eksis Riset Polnes, 8(2), 2218-2221.

Prasetijaningsih, C. (2017). Image kota baru tangerang selatan: transformasi metropolitan. no. 2 sept, 57-61.

Purwantiasning, Setyoningrum, S. (2020). Kajian Permeability dan Imageability Pada Kawasan Konservasi Clarke Quay dan Boat Quay, Singapura. Arsitektur UMJ Press.

Purwantiasning, A. W., Masruroh, F., \& Nurhidayah. (2013). Analisa kawasan boat quay berdasarkan teori kevin lynch. NALARs, 12(1), 59-72.

Silavi T, Farshad H, Christophe C, dan F. N. (2017). The Legibility and Permeability of Cities: Examining the Role of Spatial Data and Metrics. 1-20.

Tohjjiwa, A. D. (2014). Citra Pusat Kota Depok Berdasarkan Peta Kognitif Pengamat.

Wahab, Sitti R,. Rundonuwu, Dwight., P. (2018). Kajian Elemen Pembentuk Citra Kota Bitung. Spasial, 5(2), $238-248$.

Wijaya, K., Wibowo, H., \& Permana, A. Y. (2019). Identitas Kawasan Kampung Paralon Di Permukiman Padat. Jurnal Arsitektur Zonasi, 2, 193-199.

Yavuz, A, dan Kuloğlu, N. (2014). Permeability as an Indicator of Environmental Quality: Physical, Function, Perceptual Components of The Environment. World Journal of Environmental Research, 29-40. 